\title{
BUILDING INFORMATION AND INNOVATION MOVE MODEL FOR SMES INNOVATION IMPROVEMENT IN ARISING ECONOMIES
}

\author{
Triasari Oktavriana \\ Industrial Engineering Department, Udayana University Rectorate, Indonesia
}

\section{ABSTRACT}

Innovation advancements happen in stages. The stages start by finding logical information produced from fundamental exploration. The discoveries of essential exploration are utilized to create improvements related with its 'materialness', and are then evolved and tried as per information, financially applicable strategies, and actually solid (advancement measure) methodology. Additionally, top to bottom information examination (learning measure) will create advancement of gear, cycles, and items. Developments will go through a course of transformation (variation measure) to fulfill specialized guidelines, efficiency, and social impact of innovation application. This paper develops a model of practical information and innovation.

KEYWORDS:- Innovation Move; SMEs; Practical; On-going premise; Arising economies.

\section{INTRODUCTION}

The point of this review is to remake the essential components of maintainable information and innovation move and give a contemporary hypothetical and hands on work support for these variables inside the setting of SMEs in creating economies. The accomplishment of any program that tries to accomplish an exchange of innovation has a critical reliance on outside assets like the transferor and the actual program. Specifically, this exploration proposes the thoughts of whether the information and innovation move program can be presented on a manageable premise. It is fought that for the best outcomes, innovation move ought not be acted in one-off programs; rather it should be performed on a reasonable premise.

\section{Methods}

The fundamental contention feasible innovation move is that without any transferee ability to keep up with, fix, work and foster a specialized framework related with another innovation, innovation move turns into a one-time mediation. It is basic that an organization's upper-level administration and neighborhood the executives be associated with innovation move programs in managing social issues, for instance concerning how mediations that have 
CURRENT RESEARCH JOURNAL OF PEDAGOGICS 2(10): 22-24, October

2021 DOI: https://doi.org/10.37547/pedagogics-crjp-02-10-05

ISSN 2767-3278

(C)2021 Master Journals

\section{Crossref do) 8 Google}

Accepted 19th October, 2021 \& Published 24th October, 2021

been carried out can be supported by the foundation and through friendly collaboration and constructions. Through innovation move, another information and innovation is adjusted (transformation measure). The new adjusted information and innovation would then be able to further develop the transferee innovation ability. Top to bottom information examination (learning measure) will create measure development. Developments will go through a course of variation (transformation measure) that will lead a course of advancement which then, at that point, could be adjusted once more. The aggregate of an innovation move program follows the rationale of economical cycles. As for the transferee association, maintainability is the on-going eagerness of the association to be engaged with innovation move programs; and, as far as change, the on-going course of adaptationinnovation-capacity to get selfsupporting improvement.

\section{SMALL TO MEDIUM ENTERPRISES}

The justifications for why SMEs are a significant subject in Indonesia incorporate.

1. Owing to fairness issues - probably in light of the fact that ethnic relations are extremely delicate politically in Indonesia - SMEs have been utilized in advancing native Indonesian business.

2. SMEs assume an essential part in producing an economy's turn of events.

3. The global experience shows that productive SMEs create modern development and an adaptable modern construction. Taiwan regularly is held out to act as an illustration of an economy based on the establishments of a productive SME area.
The quantity of Indonesia SMEs was assessed to be 42.4 million, and they contributed up to $56.7 \%$ of Gross domestic product, represented $19.4 \%$ of all out trades, and utilized 79 million individuals. In the Indonesian assembling area, there were more than 2.5 million (99.9\%) producing SMEs in 2005, contrasted with just 2,519 (0.1\%) fabricating LEs (Indonesian Division of Participation and SMEs) and right now, SMEs gave work to roughly 8.5 million individuals $(80 \%$ of those utilized inside the Indonesian assembling area) contrasted with LEs utilizing around 2.4 million individuals (20\%). Regardless of their significant job in homegrown financial and modern advancement in Indonesia, SMEs progressively need to effectively contend in both provincial and global exchanging markets. This is a climate with complex connections, fast innovation upgrade, and contest.

\section{Information and innovation move programs}

Government-started information and innovation move in Indonesia is ordinarily finished through government services and their related offices, between service divisions and neighborhood government. Government gave preparing projects and mastery move, just as actual gear (hardware and devices) to SMEs. Huge ventures (Les) were observed to be involved and given profoundly engaged preparing projects to SME representatives. The projects have, for instance, "looked to empower further developed abilities in item normalization, empowering SMEs to then stockpile items with the necessary quality to these bigger organizations through further developed skill.

PROPOSED MODEL OF Manageable Innovation Move 
CURRENT RESEARCH JOURNAL OF PEDAGOGICS 2(10): 22-24, October

2021 DOI: https://doi.org/10.37547/pedagogics-crjp-02-10-05

ISSN 2767-3278

(C)2021 Master Journals

Crossref do: 81 Google

Accepted 19th October, 2021 \& Published 24th October, 2021

An audit of the applicable writing and the consequences of the fundamental hands on work research were utilized as establishments to devise a proposed maintainable information and innovation move model exploration that will help the formation of a proposed computational model. Elements influencing manageable information and innovation move are investigated to recognize the connections among those factors that help the proposed model. An orderly and steady cycle is applied. The fundamental builds are recognized and connections between develops are separated. The consequences of these examinations will be introduced in diagrammatic structure.

\section{Cycles}

The following expansive build bunch is 'measures'. This develop addresses the primary exercises in information and innovation move. The way that the extent of this examination is limited to information and innovation move programs gives some help in producing the rundown of moving cycles. Inspecting information and innovation move, and the phases of innovation improvement writing proposes that the accompanying cycles are the central determinants of effective innovation move programs.

\section{Manageable Innovation Move Model}

The worth of a coordinating system for exploring the expansiveness of innovation move was distinguished in the fundamental speculations. Partners, Data sources, Cycles and Results are the rundown of develop groupings that are considered to be adequately far reaching to guarantee that all striking parts of maintainable innovation move are covered.

\section{ReFERENCES}

1. Thijittang, S. (2010). A Study of Pragmatic Strategies of English of Thai University Students: Apology Speech Acts. Ph.D. Thesis. University of Tasmania: Australia

2. Dudley, E.1993. The Critical Villager: Beyond Community Participation. London: Routledge, in Clements et al (2003).

3. Handoko, F., Smith, A., Indriani, S., 2017. The role of Tacit and Codified Knowledge within Technology Transfer Program on Technology Adaptation. International Journal of Engineering and Management (IJEM), Vol. 1, No. 1, Aug, 2017 pp.35.

4. Hong, Jon-Chao, 1994. Technology Transfer and Human Resource Development. Industrial and Commercial Trainning, Vol. 26 No. 11, 1994, pp. 17-21. MCB University Press, 00197858.

5. Kemmis, S. and McTaggart, R., 2005; Research: Communicative Action and the Public Sphere. Chapter 23 in Denzin, N. and Lincoln, Y. (eds.) Handbook of Qualitative Research, 3rd edition. Thousand Oaks, California: Sage. 